\title{
Phase I study investigating the safety and feasibility of combining imatinib mesylate (Gleevec) with sorafenib in patients with refractory castration-resistant prostate cancer
}

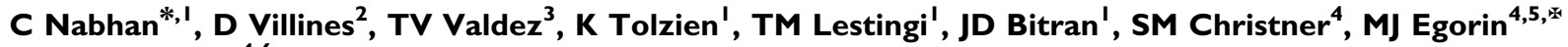 and JH Beumer ${ }^{4,6}$}

'Department of Medicine, Division of Hematology and Oncology, Advocate Lutheran General Hospital, Park Ridge, IL, USA; ${ }^{2}$ Department of Research and Biostatistics, Advocate Lutheran General Hospital, Park Ridge, IL, USA; ${ }^{3}$ Department of Medicine, Advocate Lutheran General Hospital, Park Ridge, IL, USA; ${ }^{4}$ Molecular Therapeutics/Drug Discovery Program, University of Pittsburgh Cancer Institute, Pittsburgh, PA, USA; ${ }^{5}$ Division of Hematology/ Oncology, Department of Medicine, University of Pittsburgh School of Medicine, Pittsburgh, PA, USA; ${ }^{6}$ Department of Pharmaceutical Sciences, University of Pittsburgh School of Pharmacy, Pittsburgh, PA, USA

BACKGROUND: Determining the maximum tolerated dose (MTD) and the dose-limiting toxicity (DLT) of sorafenib (S) plus imatinib (IM) in castration-resistant prostate cancer (CRPC) patients.

METHODS: Refractory CRPC patients were enrolled onto this $3+3$ dose escalation designed study. Imatinib pharmacokinetics (PK) were determined on day I5, $4 \mathrm{~h}$ post dose with a validated LC-MS assay.

RESULTS: Seventeen patients were enrolled; 10 evaluable (6 at $400 \mathrm{mg} \mathrm{S}$ qd with $300 \mathrm{mg}$ IM qd (DL0) and 4 at $400 \mathrm{mg}$ S bid with $300 \mathrm{mg}$ IM qd (DLI)); inevaluable patients received < I cycle. The median age was 73 (57-89); median prostatic serum antigen was $284 \mathrm{ng} \mathrm{ml}^{-1}$ ( I l.7-9027). Median number of prior non-hormonal therapies was 3 (1-12). Dose-limiting toxicities were diarrhoea and hand-foot syndrome. Maximum tolerated dose was $400 \mathrm{mg} \mathrm{S}$ and $300 \mathrm{mg}$ IM both daily. No biochemical responses were observed. Two patients had stable disease by RECIST. Median time to progression was 2 months (I-5). Median OS was 6 months $(1-30+)$ with $3 / 17$ patients $(17 \%)$ alive at 21 months median follow-up. Ten patients had PK data suggesting that $S$ reduced IM clearance by $55 \%$, resulting in $77 \%$ increased exposure $(P=0.005$; compared with historical data).

CONCLUSION: This is the first report showing that S + IM can be administered in CRPC at a dose of $400 \mathrm{mg} \mathrm{S}$ and $300 \mathrm{mg} I \mathrm{M}$, daily. British Journal of Cancer (2012) 1 07, 592-597. doi:I0.1038/bjc.2012.312 www.bjcancer.com

Published online 17 July 2012

(C) 2012 Cancer Research UK

Keywords: prostate cancer; imatinib; sorafenib; castration-resistant; hormone refractory; Gleevec

While chemotherapy with docetaxel-based regimens has improved outcomes of patients with castration-resistant prostate cancer (CRPC), the median overall survival (OS) is 20 months and $<25 \%$ of patients are alive at 3 years (Petrylak et al, 2004; Tannock et al, 2004; Berthold et al, 2008). Until recently, there were no therapeutic options for patients who failed docetaxel. Recently, cabazitaxel and abiraterone have shown improved survival in this setting (de Bono et al, 2010, 2011). Also, sipuleucel-T autologous immunotherapy proved to be effective in asymptomatic or minimally symptomatic CRPC patients including these who had received prior chemotherapy (Kantoff et al, 2010). Although these newer therapies fulfil a critical void in the treatment paradigm for CRPC, additional effective therapies are urgently needed.

Platelet-derived growth factor receptor (PDGFR) is a transmembrane tyrosine kinase receptor that is overexpressed in the majority of bone metastases and in primary prostatic adenocarcinoma tissues, (George, 2002) and has been implicated in CRPC progression and evolution of bone metastases (Chott et al, 1999;

\footnotetext{
*Correspondence: Dr C Nabhan; E-mail: cnabhan@oncmed.net

Deceased.

Received 5 March 2012; revised 7 June 2012; accepted I8 June 2012; published online 17 July 2012
}

Ko et al, 2001). Also, immunohistochemical studies have suggested overexpression of PDGFR genes and the receptor ligand in primary prostate cancer cells (Fudge et al, 1994; Singh et al, 2002). Furthermore, animal studies of prostate cancer models have shown activity for PDGFR inhibitors, such as imatinib (IM), especially when combined with cytotoxic therapy (Buchdunger et al, 2000).

Kim et al (2006) showed that inhibiting phosphorylation of PDGFR using IM and paclitaxel reduces the incidence and size of human prostate cancer bone lesions in nude mice. Further, tumour-associated endothelial cells, rather than tumour cells themselves, appeared to be the target for IM in prostate cancer bone metastasis. Kubler et al (2005) examined the cytotoxic effects of IM in combination with other anticancer agents in several human prostate cancer cell lines that were exposed to IM and to other cytotoxic drugs simultaneously for 5 days. These investigators showed that IM produced additive effects in two of three cell lines when combined with etoposide. Contradictory results were noted when IM was combined with docetaxel.

Sorafenib (S) is a multi-kinase inhibitor that inhibits tumour growth by a dual mechanism, acting either directly on the tumour (through inhibition of Raf and Kit signalling) and/or on tumour angiogenesis (through inhibition of VEGFR and PDGFR signalling) (Adnane et al, 2006). As both pathways are implicated in the evolution of CRPC, $S$ was studied in this setting (Dahut et al, 2008; Safarinejad, 2010). 
Collectively, these data suggest modest activity for IM and S as single agents and argue that investigations of combining both these drugs in patients with CRPC are warranted. Accordingly, we initiated a phase I study to investigate the safety of combining IM and $S$ and to determine the maximum tolerated dose (MTD) for future studies. Herein, we report the final results of this phase I study.

\section{PATIENTS AND METHODS}

\section{Major inclusion and exclusion criteria}

Men with histologically confirmed CRPC, regardless of their original Gleason score, who had failed one or more lines of systemic chemotherapy, were eligible as long as their last treatment was $\geqslant 4$ weeks prior. Progression on the last chemotherapy had to be confirmed radiographically and/or biochemically. Patients had to have measurable disease by bone scan and/or computed tomography (CT), an ECOG (Eastern Cooperative Oncology Group) performance status $\leqslant 2$, and adequate organ function (total bilirubin $<1.5 \times$ upper normal limit, AST/ALT $<2.5$ upper normal limit, creatinine $<1.5$ upper normal limit, platelets $>75 \times 10^{9}$ per 1 , and absolute neutrophil counts $>1.0 \times 10^{9}$ per l). Patients were mandated to continue ADT while on study and were allowed to continue bisphosphonates for bone metastases. Continuing ADT and bisphosphonates in these patients was recommended based on common standard practice in CRPC patients and based on the NCCN guidelines in this setting (Mohler et al, 2010). Patients with prior malignancies (except for non-melanoma skin cancers) were excluded unless any active therapy for such malignancy was $>3$ years from study entry. Patients with known HIV status or brain metastases were excluded. Other major exclusion parameters included New York Heart Association class III/IV, uncontrolled hypertension defined as systolic $>150 \mathrm{~mm} \mathrm{Hg}$ and/or diastolic $>90 \mathrm{~mm} \mathrm{Hg}$ despite optimal therapy, active infectious or psychiatric illness, thrombotic or embolic events within 6 months from enrolment, pulmonary haemorrhage, bleeding event $>$ grade 3 both within 4 weeks from study entry, use of St John's Wort or rifampin, known cirrhosis or active hepatitis, prior radiotherapy to $>25 \%$ of the bone marrow, and major surgery within 2 weeks of study entry. All patients understood and signed a written informed consent. The study was approved by the Institutional Review Board of the Advocate Lutheran General Hospital, and was conducted in accordance with the ethical principles of the World Medical Association Declaration of Helsinki. The study was registered at www.clinicaltrials.gov (NCT 00424385).

\section{Study objectives}

The primary objective was to determine the MTD and doselimiting toxicities (DLTs) of the combination of S and IM in CRPC patients who have failed one or more lines of systemic chemotherapy. Secondary endpoints included the assessment of the IM pharmacokinetics $(\mathrm{PK})$ in combination with $\mathrm{S}$, calculating the Overall Clinical Benefit (measured as the sum of complete response (CR), partial response (PR), and stable disease (SD)), and calculating time to disease progression.

\section{Study design}

Eligible patients were enrolled in cohorts of three starting at dose level 0 and escalated per study guidelines (Table 1). Dose levels -1 and -2 were included as back-down levels if dose level 0 proved too toxic. The MTD was defined as the dose at which $>1 / 6$ patients experienced DLT in cycle 1 . Each cycle was 4 weeks of therapy.
Table I Planned dose escalation schema

\begin{tabular}{lcc}
\hline Dose level & Sorafenib dose & Imatinib dose \\
\hline-2 & $200 \mathrm{mg}$ daily & $200 \mathrm{mg}$ daily \\
-1 & $200 \mathrm{mg}$ daily & $300 \mathrm{mg}$ daily \\
0 & $400 \mathrm{mg}$ daily & $300 \mathrm{mg}$ daily \\
1 & $400 \mathrm{mg}$ twice daily & $300 \mathrm{mg}$ daily \\
2 & $400 \mathrm{mg}$ twice daily & $400 \mathrm{mg}$ daily \\
3 & $400 \mathrm{mg}$ twice daily & $600 \mathrm{mg}$ daily \\
4 & $400 \mathrm{mg}$ twice daily & $400 \mathrm{mg}$ twice daily \\
\hline
\end{tabular}

\section{Toxicity assessment}

Toxicity was scored according to the Common Terminology Criteria for Adverse Events (version 3). Toxicity was assessed weekly in cycle 1 , followed by monthly assessments thereafter. A DLT was defined as any drug-related grade 4 toxicity or any recurring grade 3 non-haematological toxicity. A single DLT event resulted in expansion to a cohort of six patients, and two or more DLTs would result in expansion of the previous dose level to six evaluable patients. Patients who did not have a DLT were allowed to continue on therapy as long as there was no progression. Hand-foot syndrome (HFS) was considered a DLT but nonhaematological skin toxicities <grade 3 were not considered a DLT. Patients, who withdrew from the study because of a non- haematological skin toxicity, based on their preference rather than toxicity, were not considered to have had a DLT. Grade 3 hypertension or symptomatic grade 2 hypertension that persisted more than 21 days after holding $S$ despite maximal medical management was also considered a DLT. Patients were considered inevaluable if toxicity was not considered drug related, or if they did not complete cycle 1 for other reasons than toxicity.

\section{Dose modifications}

For any grade 1 or 2 toxicity (haematological or non-haematological), both drugs were continued after implementation of standard supportive measures. For grade 3 non-haematological toxicity, both drugs were held until toxicity $\leqslant 1$ after which treatment was allowed at the same dose level. Recurring grade 3 nonhaematological toxicity resulted in a dose reduction. When grade 4 toxicity occurred, both study drugs were held as that would have been considered a DLT. Resumption at a reduced dose level after toxicity decreased to $\leqslant$ grade 1 was allowed at the investigator's discretion only if response or stable disease had been witnessed.

\section{Laboratory and radiographic assessment}

Laboratory studies included complete blood count, complete metabolic panel, serum testosterone and prostatic serum antigen (PSA) done within 14 days from starting therapy. Same laboratory studies except testosterone and PSA were repeated every 4 weeks (every cycle). Prostatic serum antigen, bone scans and CT-scans and/or magnetic resonance imaging were done before starting therapy and every two cycles thereafter.

\section{Efficacy assessment}

RECIST version 1 was used to assess radiographic response to treatment (Tsuchida and Therasse, 2001). To document PSA response, serum PSA was measured every 8 weeks while patients were on study. For patients with measurable disease, a PSA increase in the absence of measurable disease progression was not considered progression. For patients with a PSA $\geqslant 20 \mathrm{ng} \mathrm{dl}^{-1}$; A PSA CR was defined as a non-detectable PSA $\left(<4 \mathrm{ng} \mathrm{dl}^{-1}\right)$ confirmed on a repeat measurement 3 weeks later. A PSA PR was 
defined as a PSA decrease of $>50 \%$ maintained for at least 3 weeks. Stable PSA was defined as a PSA increase $\leqslant 25 \%$ or a decrease $<50 \%$. Prostatic serum antigen progression was defined as an increase $>25 \%$. For patients with a PSA $\leqslant 20 \mathrm{ng} \mathrm{dl}^{-1}$ at baseline, PSA progression was defined as an increase by $100 \%$ or more confirmed after 3 weeks. The duration of the PSA response was defined as the time between the first and last evaluations at which the response criteria were met.

\section{Pharmacokinetic analysis}

Blood samples for IM PK were collected in heparinised tubes at $\sim 4 \mathrm{~h}$ after the day 15 dose of IM. Plasma was prepared by centrifugation and immediately frozen at $-20^{\circ} \mathrm{C}$. Plasma concentrations of IM and its active metabolite, CGP74588, were determined with a validated LC-MS assay (Parise et al, 2003). Statistical analyses of concentration values were performed using SPSS 19.0 for Windows (SPSS Inc., Chicago, IL, USA) by two-tailed Student's $t$-test on natural log-transformed data for which a value of $P<0.05$ was considered significant.

\section{RESULTS}

\section{Patient characteristics}

Patient baseline characteristics are detailed in Table 2. Seventeen patients were enrolled (13 on dose level 0 and 4 on dose level 1), of which 7 received $<1$ cycle of therapy, and were considered inevaluable for efficacy or DLT analysis but were included in overall toxicity assessment. Median age was 73 (range 57-89) and median PSA was $284 \mathrm{ng} \mathrm{dl}^{-1}$ (range 11.7-9027.4). Median number of non-hormonal systemic chemotherapy regimens received before enrolment was 3 (range 1-12).

Table 2 Patient characteristics

\begin{tabular}{|c|c|}
\hline Number of patients & $17(100 \%)$ \\
\hline Dose level 0 (evaluable) & $13(6)$ \\
\hline Dose level I (evaluable) & $4(4)$ \\
\hline Median age (range) & $73(57-89)$ \\
\hline Race & $\begin{array}{c}\text { White: I6 } \\
\text { Asian: I }\end{array}$ \\
\hline ECOG performance status & $\begin{array}{l}0=4 \\
1=11 \\
2=2\end{array}$ \\
\hline Gleason score & $\begin{array}{l}\geqslant 7=12 \\
<7=2 \\
N A=3\end{array}$ \\
\hline $\begin{array}{l}\text { Median PSA (range } \mathrm{ng} \mathrm{ml}^{-1} \text { ) } \\
\text { Median number of chemotherapy regimens } \\
\text { Median alkaline phosphatase value } \\
\text { Median time from diagnosis to study (months) }\end{array}$ & $\begin{array}{c}284(11.7-9027) \\
3(1-12) \\
142(59-712) \\
108(34-248)\end{array}$ \\
\hline Sites of involvement & $\begin{array}{c}\text { Bone only: I5 } \\
\text { Visceral disease: I } \\
\text { Bone and viscera: I }\end{array}$ \\
\hline Initial therapy for prostate cancer & $\begin{array}{l}\text { ADT: } 9 \\
\text { RP: } 4 \\
\text { Brach: } 2 \\
\text { EBRT: I }\end{array}$ \\
\hline
\end{tabular}

Abbrviations: $\mathrm{ADT}=$ androgen deprivation therapy; Brach = brachytherapy; $\mathrm{DLT}=$ dose-limiting toxicity; EBRT = external beam radiotherapy; ECOG = Eastern Cooperative Oncology Group; NA = not available; PSA = prostatic serum antigen; RP = radical prostatectomy.

\section{Dose escalation}

Out of the first three patients enrolled on dose level 0 , one experienced DLT, which prompted expansion to a total of six, with no further DLT. After escalation to dose level 1, four patients were enrolled, resulting in two DLTs. Accordingly, enrolment was halted and dose level 0 was determined to be the MTD. While 13 patients were initially enrolled on dose level 0, 7 did not complete the first cycle for reasons unrelated to toxicity and accordingly were inevaluable for DLT although they were included in overall toxicity analysis (5 withdrew consent, 1 had rapid early disease progression and 1 was non-compliant). Of the five who withdrew consent, one had grade 1 skin rash with PSA rise and decided to withdraw, another withdrew after he continued to have nausea and emesis that were present before starting the study, and the other three did not offer an explanation.

\section{Pharmacokinetics}

Of patients' enrolled, PK data were collected on 10 patients. Concentrations of IM and its active metabolite CGP74588 are displayed in Table 3. Concentrations were also expressed normalised to the dose of IM. The reported maximum IM plasma concentrations at steady-state at doses ranging from 200 to $750 \mathrm{mg}$ QD (Peng et al, 2004), normalised by dose, were used as reference values for the concentrations observed in the current study (Figure 1). The dose-normalised concentrations observed in the current study were 1.7-fold higher than those reported in the literature (Peng et al, 2004) $(P=0.005)$. We obtained samples at $4 \mathrm{~h}$ after dosing, which is close to the reported average $T_{\max }$ of IM (Peng et al, 2004). However, because we likely will have missed the true $T_{\max }$ in most of our patients, the currently reported concentrations are an underestimate of the true $C_{\max }$. Consequently, the calculated 1.7-fold increase is an underestimate of the observed interaction.

\section{Toxicity}

Of the first three patients on dose level 0 , one had a HFS DLT prompting enrolment of three additional patients, none of which

Table 3 Concentrations of imatinib and CGP74588 in patients receiving imatinib and sorafenib

\begin{tabular}{|c|c|c|c|c|c|}
\hline $\begin{array}{l}\text { Imatinib } \\
\text { (mg) } \\
\text { QD }\end{array}$ & $\begin{array}{c}\text { Sorafenib } \\
\text { (mg) } \\
\text { QD }\end{array}$ & $\begin{array}{l}\text { Imatinib } \\
\left(\mathrm{ng} \mathrm{ml}^{-1}\right) \\
\text { CIDI5 }\end{array}$ & $\begin{array}{c}\text { Imatinib/ } \\
\text { dose } \\
\text { (ng ml }^{-1} \\
\text { per dose) } \\
\text { CIDI5 }\end{array}$ & $\begin{array}{l}\text { CGP } \\
\left(\mathrm{ng} \mathrm{ml}^{-1}\right) \\
\text { CIDI5 }\end{array}$ & $\begin{array}{l}\text { CGP/dose } \\
\left(\mathrm{ng} \mathrm{ml}^{-1} \mathrm{mg}^{-1}\right) \\
\text { CIDI5 }\end{array}$ \\
\hline $\begin{array}{l}300 \\
300 \\
300 \\
300 \\
300 \\
300 \\
300 \\
300 \\
300 \\
300\end{array}$ & $\begin{array}{l}400 \\
400 \\
400 \\
400 \\
400 \\
400 \\
400 \\
400 \\
400 \\
400\end{array}$ & $\begin{array}{l}1955 \\
2801 \\
1866 \\
3812 \\
1166 \\
3954 \\
3392 \\
4364 \\
2423 \\
3778\end{array}$ & $\begin{array}{r}6.5 \\
9.3 \\
6.2 \\
12.7 \\
3.9 \\
13.2 \\
11.3 \\
14.6 \\
8.1 \\
12.6\end{array}$ & $\begin{array}{r}691 \\
803 \\
766 \\
981 \\
324 \\
813 \\
1301 \\
1045 \\
870 \\
1120\end{array}$ & $\begin{array}{l}2.3 \\
2.7 \\
2.6 \\
3.3 \\
1.1 \\
2.7 \\
4.3 \\
3.5 \\
2.9 \\
3.7\end{array}$ \\
\hline & $\begin{array}{l}\text { Mean } \\
\text { s.d. } \\
\text { Reference } \\
\text { value } \\
\text { (Peng et al, } \\
\text { 2004) }\end{array}$ & $P$-value* & $\begin{array}{l}9.8 \\
3.6 \\
5.6\end{array}$ & & $\begin{array}{l}2.9 \\
0.9\end{array}$ \\
\hline
\end{tabular}

* $P$-value is between data presented herein and data from reference. 
experienced DLT. Of the four patients enrolled on dose level 1, two experienced DLT (one was hand/foot ulcerative dermatitis and another was grade 3 diarrhoea that recurred when the drug was resumed after initial stop).

When evaluating any reported toxicity in all patients $(n=17)$, including those that did not complete one cycle, most witnessed non-haematological adverse events were of grade 1 or 2 (rash $47 \%$, nausea $23 \%$, vomiting $23 \%$, diarrhoea $17 \%$ ), (Table 4 ). Few patients developed grade 3 or 4 (rash, diarrhoea, dehydration, HFS in $6 \%$ each and weakness, weight loss in $12 \%$ each). Most laboratory toxicities were grade 1 or 2 (hypoalbuminemia $29 \%$, hypocalcemia $18 \%$ and elevated creatinine $18 \%$ ). Few patients developed grade 3 or 4 haematological toxicity (neutropenia $12 \%$ and lymphopenia 18\%).

\section{Efficacy}

No biochemical responses were witnessed in patients on either dose level. Only two patients on dose level 0 had radiographically

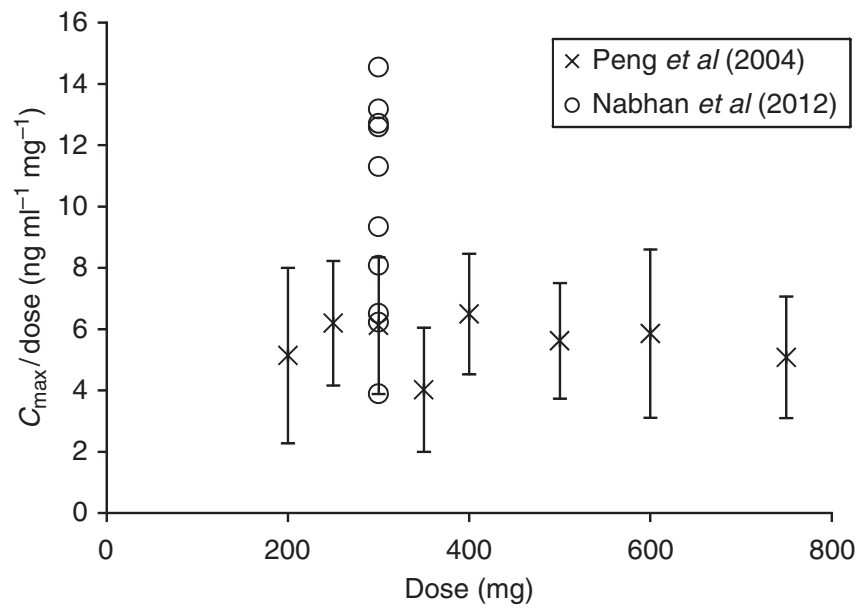

Figure I Dose-normalised imatinib concentrations of imatinib observed in the current study relative to average concentrations (with error bars indicating s.d.) as reported in the literature (Peng et al, 2004) stable disease on initial assessment while all others progressed. From a total of 10 assessable patients, the overall clinical benefit was estimated at $20 \%$. Median time to progression was 2 months (range 1-5) while median OS for the entire cohort was 6 months (range $1-30+$ ) with three patients $(17 \%)$ remaining alive at a median follow-up of 21 months. Only two patients received $>$ two cycles of therapy (one four cycles and another five cycles) while all others received two cycles or less.

\section{DISCUSSION}

In this phase I study specifically designed for relapsed and/or refractory CRPC patients, we demonstrate that combining IM and $S$ is feasible at an MTD of IM at $300 \mathrm{mg}$ and $S$ at $400 \mathrm{mg}$ both given daily. Dose-limiting toxicitiess were HFS and diarrhoea. Non-DLT toxicities were manageable and predictable given the known adverse events of either agent. Two patients had SD at their first response assessment and $17 \%$ of patients remained alive at a median follow-up of 21 months. No biochemical responses were seen although data on how targeted and biological agents affect PSA kinetics are controversial (Chi et al, 2008; Dahut et al, 2008).

Pharmacokinetics data from our study show that observed concentrations of IM are $\sim 77 \%$ higher than those expected based on reference values of single agent IM, suggesting that S may reduce IM clearance. Imatinib is a substrate for CYP3A4, CYP2D6, CYP2C9, CYP3A5, CYP4A and UDP-glucuronyltransferases (O'Brien et al, 2003; Gschwind et al, 2005). As expected, in a healthy volunteer drug-drug interaction study, co-administration of ketoconazole, a potent CYP3A4 inhibitor, resulted in an increase in mean IM $C_{\text {max }}$, and $\mathrm{AUC}_{0 \text {-inf }}$ of $26 \%$ and $40 \%$, respectively (Dutreix et al, 2004). Sorafenib is metabolised primarily in the liver by CYP3A4, and UGT1A9, with $19 \%$ of the dose being excreted in urine as glucuronidated metabolite (Kane et al, 2006), and clearly shares metabolic pathways with IM. In vitro data suggest that $S$ is a competitive inhibitor of CYP2C19, CYP2D6 and CYP3A4, but these effects were not mirrored in clinical studies (Kane et al, 2006). This would suggest that an interaction through CYP3A4 inhibition is not the likely explanation for our observation. Recent data showing that $\mathrm{S}$ can activate midazolam

Table 4 Toxicity of imatinib and sorafenib combination in CRPC

\begin{tabular}{|c|c|c|c|c|c|c|}
\hline \multicolumn{3}{|c|}{$\begin{array}{l}\text { All evaluable patients } \\
\text { for toxicity }(N=I 7)\end{array}$} & \multicolumn{2}{|c|}{$\begin{array}{c}\text { Dose level } 0 \text { (I3 patients) } \\
\text { (imatinib } 300 \mathrm{mg}+\text { sorafenib } 400 \mathrm{mg} \text { ) }\end{array}$} & \multicolumn{2}{|c|}{$\begin{array}{c}\text { Dose level I (4 patients) } \\
\text { (imatinib } 400 \mathrm{mg}+\text { sorafenib } 400 \mathrm{mg} \text { ) }\end{array}$} \\
\hline Adverse events & Grades I or 2 & Grades 3 or 4 & Grades I or 2 & Grades 3 or 4 & Grades I or 2 & Grades 3 or 4 \\
\hline Nausea & $4(23 \%)$ & 0 & $3(50 \%)$ & 0 & I (25\%) & 0 \\
\hline Vomiting & $4(23 \%)$ & 0 & $4(31 \%)$ & 0 & 0 & 0 \\
\hline Rash & $8(47 \%)$ & | (6\%) & $7(54 \%)$ & | (7.6\%) & I (25\%) & 0 \\
\hline Hand/foot & I (6\%) & | (6\%) & | (7.6\%) & 0 & 0 & | (16\%) \\
\hline Diarrhoea & $3(17 \%)$ & I (6\%) & I (7.6\%) & | (7.6\%) & $2(33 \%)$ & 0 \\
\hline Constipation & I (6\%) & 0 & | (7.6\%) & 0 & 0 & 0 \\
\hline Fatigue & $2(12 \%)$ & 0 & I (7.6\%) & 0 & I (7.6\%) & 0 \\
\hline Dehydration & $2(12 \%)$ & | (6\%) & $2(15 \%)$ & | (7.6\%) & 0 & 0 \\
\hline Weakness & $2(12 \%)$ & $2(12 \%)$ & $2(15 \%)$ & $2(15 \%)$ & 0 & 0 \\
\hline LE oedema & $2(12 \%)$ & 0 & $2(15 \%)$ & 0 & 0 & 0 \\
\hline Weight loss & 0 & | (6\%) & 0 & 0 & 0 & | (7.6\%) \\
\hline Periorbital oedema & | (6\%) & 0 & | (7.6\%) & 0 & 0 & 0 \\
\hline$\uparrow$ Creatinine & $3(18 \%)$ & | (6\%) & $3(21 \%)$ & | (7.6\%) & 0 & 0 \\
\hline Hyperglycaemia & $2(12 \%)$ & 0 & $2(15 \%)$ & 0 & 0 & 0 \\
\hline Hypocalcemia & $3(18 \%)$ & $2(12 \%)$ & $3(21 \%)$ & $2(15 \%)$ & 0 & 0 \\
\hline Elevated LFTs & $2(12 \%)$ & 0 & $2(15 \%)$ & 0 & 0 & 0 \\
\hline Neutropenia & 0 & $2(12 \%)$ & 0 & 0 & 0 & $2(33 \%)$ \\
\hline Lymphopenia & 0 & $3(18 \%)$ & 0 & $3(21 \%)$ & 0 & 0 \\
\hline Hypoalbunemia & $5(29 \%)$ & 0 & $5(38 \%)$ & 0 & 0 & 0 \\
\hline Hyponateremia & $2(12 \%)$ & 0 & $2(15 \%)$ & 0 & 0 & 0 \\
\hline
\end{tabular}

Abbreviation: $\mathrm{CRPC}=$ castration-resistant prostate cancer. 
$1^{\prime}$-hydroxylation by CYP3A5, but inhibits the same reaction through CYP3A4 indicate that it may be difficult to definitively define this interaction and that unexpected drug interactions may occur after the use of S (Sugiyama et al, 2011). Alternatively, the interaction between IM and S occurs at the level of glucuronidation. The mass balance study of IM showed that only $4 \%$ of radioactivity in plasma is represented by IM glucuronide, relative to $70 \%$ for IM parent drug (Gschwind et al, 2005), however, this may underestimate the relevance of the glucuronidation pathway. Sorafenib was able to increase the exposure of doxorubicin by $21 \%$ and the exposure of irinotecan by $26-41 \%$, while the exposure to SN-38 increased by $67-120 \%$, most likely through inhibition of UDP-glucuronyltransferases (Kane et al, 2006). Concentrations of the active metabolite CGP74588 are $10-20 \%$ those of IM parent concentrations (Peng et al, 2004; Gschwind et al, 2005), but changes in this study are difficult to interpret as formation and elimination of this metabolite are both mediated by metabolism. The increased exposure of IM may well have contributed to the toxicities observed in the current study. Unfortunately, we were not able to quantitate $S$ concentrations. Future studies of this combination should include pharmacokinetic studies to confirm the observed effects on IM exposure, and to assess S PK in the context of this combination regimen.

Although combining IM with S in CRPC has not been attempted before, several studies looked at the efficacy of either agent alone or in combination with chemotherapy. A phase II study evaluated IM at $400 \mathrm{mg}$ twice daily for 24 weeks in patients with androgen sensitive prostate cancer but with PSA progression after definitive local therapy with 9 out of 21 patients had stable PSA (Rao et al, 2005). In patients who had biochemical recurrence but no radiographic evidence of disease, IM showed activity by inducing biochemical responses (Lin et al, 2006). In more advanced stages, IM was combined safely with chemotherapy. Mathew et al (2004b) treated 28 metastatic CRPC patients with IM at $600 \mathrm{mg}$ daily for a 30 -day lead-in period before continuing IM at the same dose combined with different dosing schedules of docetaxel. Biochemical responses were witnessed at all dose levels and some patients had sustained responses. Another study further confirmed the safety of combining IM with docetaxel (Lin et al, 2007). In that study, which added estramustine to the combination, five unacceptable toxicities were reported; two of which were fatal. However, it remains unclear whether these adverse events were related to estramustine, IM or the combination. Despite the modest activity that IM has shown when combined with cytotoxic therapy, its activity as a single agent remained questionable (Mathew et al, 2004a, 2007).

Sorafenib was also studied as a single agent in CRPC in a variety of settings. Dahut et al (2008) conducted an open label phase II study using S at $400 \mathrm{mg}$ twice daily in 22 men with CRPC; of which $59 \%$ received prior chemotherapy. Of the 21 patients with progressive disease, 13 progressed only by PSA criteria in the absence of radiographic progression. Two patients were found to have dramatic radiographic improvement despite PSA progression. At a median follow-up of 27.2 months, the median PFS was 3.7 months and the median OS was 18.0 months. In chemotherapynaïve patients, Safarinejad (2010) showed that giving $S$ at $400 \mathrm{mg}$ twice daily in 6-week cycles provided a median OS of 14.6 months without any CRs in 64 treated individuals. Thirteen of 64 patients $(20 \%)$ had a radiographic PR and another $20 \%$ had $>50 \%$ reduction in serum PSA. Median response duration was 2.5 months, and median time to progression was 5.9 months. The activity of S was further confirmed in a phase II trial conducted by Steinbild et al (2007), where 55 chemotherapy-naïve CRPC patients received $S$ at $400 \mathrm{mg}$ twice daily until progression. Four patients showed stable disease by imaging, 11 had stable PSA and 2 had a PSA response at 12 weeks. Furthermore, we published a small phase II study suggested that adding $S$ to the same chemotherapy that patients progressed on, could overcome chemotherapy resistance (Nabhan et al, 2012).

The mechanisms by which prostate cancer becomes castrationresistant and refractory to systemic chemotherapy are multiple and no one mechanism is predominant (Debes and Tindall, 2004). Targeting PDGFR, BRAF and angiogenesis pathways using IM and $S$ appears attractive as both agents are oral with a toxicity profile that potentially allows administration to elderly patient population.

We conclude that the combination of S and IM is feasible in relapsed and/or refractory CRPC patients. A dose of $400 \mathrm{mg}$ of S and $300 \mathrm{mg}$ of IM is appropriate for future phase II studies. We recommend, based on this data, to initiate studies specifically designed and powered to assess response, based on RECIST criteria, and efficacy of this combination in relapsed and/or refractory CRPC. Importantly, future trials would benefit from correlative biomarker studies aimed at identifying patients that are likely to benefit from this combination.

\section{ACKNOWLEDGEMENTS}

JHB and MJE were supported by grant P30-CA47904 from the National Cancer Institute. JHB is the recipient of a Hillman Fellows for Innovative Cancer Research Award. MJE is the recipient of an American Society of Clinical Oncology Cancer Foundation Translational Research Professorship. Research funding from Novartis was provided; Sorafenib was provided by Onyx Pharmaceuticals.

\section{REFERENCES}

Adnane L, Trail PA, Taylor I, Wilhelm SM (2006) Sorafenib (BAY 43-9006, Nexavar), a dual-action inhibitor that targets RAF/MEK/ERK pathway in tumor cells and tyrosine kinases VEGFR/PDGFR in tumor vasculature. Methods Enzymol 407: 597-612

Berthold DR, Pond GR, Soban F, de Wit R, Eisenberger M, Tannock IF (2008) Docetaxel plus prednisone or mitoxantrone plus prednisone for advanced prostate cancer: updated survival in the TAX 327 study. J Clin Oncol 26(2): 242-245

Buchdunger E, Cioffi CL, Law N, Stover D, Ohno-Jones S, Druker BJ, Lydon NB (2000) Abl protein-tyrosine kinase inhibitor STI571 inhibits in vitro signal transduction mediated by c-kit and plateletderived growth factor receptors. J Pharmacol Exp Ther 295(1): $139-145$

Chi KN, Ellard SL, Hotte SJ, Czaykowski P, Moore M, Ruether JD, Schell AJ, Taylor S, Hansen C, Gauthier I, Walsh W, Seymour L (2008) A phase II study of sorafenib in patients with chemo-naive castration-resistant prostate cancer. Ann Oncol 19(4): 746-751

Chott A, Sun Z, Morganstern D, Pan J, Li T, Susani M, Mosberger I, Upton MP, Bubley GJ, Balk SP (1999) Tyrosine kinases expressed in vivo by human prostate cancer bone marrow metastases and loss of the type 1 insulin-like growth factor receptor. Am J Pathol 155(4): $1271-1279$

Dahut WL, Scripture C, Posadas E, Jain L, Gulley JL, Arlen PM, Wright JJ, Yu Y, Cao L, Steinberg SM, Aragon-Ching JB, Venitz J, Jones E, Chen CC, Figg WD (2008) A phase II clinical trial of sorafenib in androgen-independent prostate cancer. Clin Cancer Res 14(1): 209-214

de Bono JS, Logothetis CJ, Molina A, Fizazi K, North S, Chu L, Chi KN, Jones RJ, Goodman Jr OB, Saad F, Staffurth JN, Mainwaring P, Harland S, Flaig TW, Hutson TE, Cheng T, Patterson H, Hainsworth JD, Ryan CJ, Sternberg CN, Ellard SL, Flechon A, Saleh M, Scholz M, Efstathiou E, Zivi A, Bianchini D, Loriot Y, Chieffo N, Kheoh T, Haqq CM, Scher HI (2011) Abiraterone and increased survival in metastatic prostate cancer. $N$ Engl J Med 364(21): 1995-2005 
de Bono JS, Oudard S, Ozguroglu M, Hansen S, Machiels JP, Kocak I, Gravis G, Bodrogi I, Mackenzie MJ, Shen L, Roessner M, Gupta S, Sartor AO (2010) Prednisone plus cabazitaxel or mitoxantrone for metastatic castration-resistant prostate cancer progressing after docetaxel treatment: a randomised open-label trial. Lancet 376(9747): 1147-1154

Debes JD, Tindall DJ (2004) Mechanisms of androgen-refractory prostate cancer. N Engl J Med 351(15): 1488-1490

Dutreix C, Peng B, Mehring G, Hayes M, Capdeville R, Pokorny R, Seiberling M (2004) Pharmacokinetic interaction between ketoconazole and imatinib mesylate (Glivec) in healthy subjects. Cancer Chemother Pharmacol 54(4): 290-294

Fudge K, Wang CY, Stearns ME (1994) Immunohistochemistry analysis of platelet-derived growth factor $\mathrm{A}$ and $\mathrm{B}$ chains and platelet-derived growth factor alpha and beta receptor expression in benign prostatic hyperplasias and Gleason-graded human prostate adenocarcinomas. Mod Pathol 7(5): 549-554

George DJ (2002) Receptor tyrosine kinases as rational targets for prostate cancer treatment: platelet-derived growth factor receptor and imatinib mesylate. Urology 60(3 Suppl 1): 115-121; discussion 122

Gschwind HP, Pfaar U, Waldmeier F, Zollinger M, Sayer C, Zbinden P, Hayes M, Pokorny R, Seiberling M, Ben-Am M, Peng B, Gross G (2005) Metabolism and disposition of imatinib mesylate in healthy volunteers. Drug Metab Dispos 33(10): 1503-1512

Kane RC, Farrell AT, Saber H, Tang S, Williams G, Jee JM, Liang C, Booth B, Chidambaram N, Morse D, Sridhara R, Garvey P, Justice R, Pazdur R (2006) Sorafenib for the treatment of advanced renal cell carcinoma. Clin Cancer Res 12(24): 7271-7278

Kantoff PW, Higano CS, Shore ND, Berger ER, Small EJ, Penson DF, Redfern CH, Ferrari AC, Dreicer R, Sims RB, Xu Y, Frohlich MW, Schellhammer PF (2010) Sipuleucel-T immunotherapy for castrationresistant prostate cancer. $N$ Engl J Med 363(5): 411-422

Kim SJ, Uehara H, Yazici S, Busby JE, Nakamura T, He J, Maya M, Logothetis C, Mathew P, Wang X, Do KA, Fan D, Fidler IJ (2006) Targeting platelet-derived growth factor receptor on endothelial cells of multidrug-resistant prostate cancer. J Natl Cancer Inst 98(11): 783-793

Ko YJ, Small EJ, Kabbinavar F, Chachoua A, Taneja S, Reese D, DePaoli A, Hannah A, Balk SP, Bubley GJ (2001) A multi-institutional phase ii study of SU101, a platelet-derived growth factor receptor inhibitor, for patients with hormone-refractory prostate cancer. Clin Cancer Res 7(4): 800-805

Kubler HR, van Randenborgh H, Treiber U, Wutzler S, Battistel C, Lehmer A, Wagenpfeil S, Hartung R, Paul R (2005) In vitro cytotoxic effects of imatinib in combination with anticancer drugs in human prostate cancer cell lines. Prostate 63(4): 385-394

Lin AM, Rini BI, Derynck MK, Weinberg V, Park M, Ryan CJ, Rosenberg JE, Bubley G, Small EJ (2007) A phase I trial of docetaxel/estramustine/ imatinib in patients with hormone-refractory prostate cancer. Clin Genitourin Cancer 5(5): 323-328

Lin AM, Rini BI, Weinberg V, Fong K, Ryan CJ, Rosenberg JE, Fong L, Small EJ (2006) A phase II trial of imatinib mesylate in patients with biochemical relapse of prostate cancer after definitive local therapy. BJU Int 98(4): 763-769

Mathew P, Fidler IJ, Logothetis CJ (2004a) Combination docetaxel and platelet-derived growth factor receptor inhibition with imatinib mesylate in prostate cancer. Semin Oncol 31(2 Suppl 6): 24-29

Mathew P, Thall PF, Bucana CD, Oh WK, Morris MJ, Jones DM, Johnson MM, Wen S, Pagliaro LC, Tannir NM, Tu SM, Meluch AA, Smith L, Cohen L, Kim SJ, Troncoso P, Fidler IJ, Logothetis CJ (2007) Plateletderived growth factor receptor inhibition and chemotherapy for castration-resistant prostate cancer with bone metastases. Clin Cancer Res 13(19): 5816-5824
Mathew P, Thall PF, Jones D, Perez C, Bucana C, Troncoso P, Kim SJ, Fidler IJ, Logothetis C (2004b) Platelet-derived growth factor receptor inhibitor imatinib mesylate and docetaxel: a modular phase I trial in androgen-independent prostate cancer. J Clin Oncol 22(16): 3323-3329

Mohler J, Bahnson RR, Boston B, Busby JE, D'Amico A, Eastham JA, Enke CA, George D, Horwitz EM, Huben RP, Kantoff P, Kawachi M, Kuettel M, Lange PH, Macvicar G, Plimack ER, Pow-Sang JM, Roach 3rd M, Rohren E, Roth BJ, Shrieve DC, Smith MR, Srinivas S, Twardowski P, Walsh PC (2010) NCCN clinical practice guidelines in oncology: prostate cancer. J Natl Compr Canc Netw 8(2): 162-200

Nabhan C, Cygan P, Meyer A, Tolzien K, Galvez A, Lestingi T, Bitran J (2012) Overcoming chemotherapy resistance in patients with chemotherapyfailure, castration-resistant prostate cancer (CRPC) with SOR. J Clin Oncol 30(suppl 5): abstract 127

O’Brien SG, Meinhardt P, Bond E, Beck J, Peng B, Dutreix C, Mehring G, Milosavljev S, Huber C, Capdeville R, Fischer T (2003) Effects of imatinib mesylate (STI571, Glivec) on the pharmacokinetics of simvastatin, a cytochrome p450 3A4 substrate, in patients with chronic myeloid leukaemia. Br J Cancer 89(10): 1855-1859

Parise RA, Ramanathan RK, Hayes MJ, Egorin MJ (2003) Liquid chromatographic-mass spectrometric assay for quantitation of imatinib and its main metabolite (CGP 74588) in plasma. J Chromatogr B Analyt Technol Biomed Life Sci 791(1-2): 39-44

Peng B, Hayes M, Resta D, Racine-Poon A, Druker BJ, Talpaz M, Sawyers CL, Rosamilia M, Ford J, Lloyd P, Capdeville R (2004) Pharmacokinetics and pharmacodynamics of imatinib in a phase I trial with chronic myeloid leukemia patients. J Clin Oncol 22(5): 935-942

Petrylak DP, Tangen CM, Hussain MH, Lara Jr. PN, Jones JA, Taplin ME, Burch PA, Berry D, Moinpour C, Kohli M, Benson MC, Small EJ, Raghavan D, Crawford ED (2004) Docetaxel and estramustine compared with mitoxantrone and prednisone for advanced refractory prostate cancer. N Engl J Med 351(15): 1513-1520

Rao K, Goodin S, Levitt MJ, Dave N, Shih WJ, Lin Y, Capanna T, DoyleLindrud S, Juvidian P, DiPaola RS (2005) A phase II trial of imatinib mesylate in patients with prostate specific antigen progression after local therapy for prostate cancer. Prostate 62(2): 115-122

Safarinejad MR (2010) Safety and efficacy of sorafenib in patients with castrate resistant prostate cancer: a Phase II study. Urol Oncol 28(1): $21-27$

Singh D, Febbo PG, Ross K, Jackson DG, Manola J, Ladd C, Tamayo P, Renshaw AA, D'Amico AV, Richie JP, Lander ES, Loda M, Kantoff PW, Golub TR, Sellers WR (2002) Gene expression correlates of clinical prostate cancer behavior. Cancer Cell 1(2): 203-209

Steinbild S, Mross K, Frost A, Morant R, Gillessen S, Dittrich C, Strumberg D, Hochhaus A, Hanauske AR, Edler L, Burkholder I, Scheulen M (2007) A clinical phase II study with sorafenib in patients with progressive hormone-refractory prostate cancer: a study of the CESAR Central European Society for Anticancer Drug Research-EWIV. Br J Cancer 97(11): 1480-1485

Sugiyama M, Fujita K, Murayama N, Akiyama Y, Yamazaki H, Sasaki Y (2011) Sorafenib and sunitinib, two anticancer drugs, inhibit CYP3A4mediated and activate CY3A5-mediated midazolam 1'-hydroxylation. Drug Metab Dispos 39(5): 757-762

Tannock IF, de Wit R, Berry WR, Horti J, Pluzanska A, Chi KN, Oudard S, Theodore C, James ND, Turesson I, Rosenthal MA, Eisenberger MA (2004) Docetaxel plus prednisone or mitoxantrone plus prednisone for advanced prostate cancer. $N$ Engl J Med 351(15): 1502-1512

Tsuchida Y, Therasse P (2001) Response evaluation criteria in solid tumors (RECIST): new guidelines. Med Pediatr Oncol 37(1): 1-3

This work is published under the standard license to publish agreement. After 12 months the work will become freely available and the license terms will switch to a Creative Commons Attribution-NonCommercial-Share Alike 3.0 Unported License. 